\title{
Community Mental Health Services in Italy
}

\section{Внебольничные службы охраны психического здоровья в Италии} doi:10.17816/CP76

\author{
(C) Gaia Sampogna, Valeria Del Vecchio, Corrado \\ De Rosa, Vincenzo Giallonardo, Mario Luciano, \\ Carmela Palummo, Matteo Di Vincenzo, \\ Andrea Fiorillo \\ Department of Psychiatry, University of Campania \\ "Luigi Vanvitelli", Naples, Italy
}

\author{
(C) Гайя Сампонья, Валерия Дель Веккьо, \\ Коррадо де Роса, Винченцо Джаллонардо, \\ Марио Лучано, Кармела Палуммо, \\ Маттэо Ди Винченцо, Андреа Фиорилло \\ Кафедра психиатрии Университета региона Кампания \\ "Луиджи Ванвителли», Неаполь, Италия
}

\begin{abstract}
In 1978, in Italy, approval of Basaglia's reform law marked a shift from an asylum-based to a community-based mental health system. The main aim of the reform was to treat patients in the community and no longer in psychiatric hospitals. Following the Italian model, similar reforms of mental health care have been approved worldwide. The communitybased model aims to promote integration and human rights for people with mental disorders on the basis of their freedom to choose treatment options.

By 2000, all psychiatric hospitals had been closed and all patients discharged. Mental health care is organized through the Department of Mental Health, which is the umbrella organization responsible for specialist mental health care in the community; this includes psychiatric wards located in general hospitals, residential facilities, mental health centres, and day-hospital and day-care units.

Approval of Law 180 led to a practical and ideological shift in the provision of care to patients with mental disorders. In particular, the reform highlighted the need to treat patients in the same way as any other patient, and mental health care moved from a custodialistic to a therapeutic model.

Progressive consolidation of the community-based system of mental health care in Italy has been observed in the past 40 years. However, some reasons for concern still exist, including low staffing levels, potential use of community residential facilities as long-stay residential services, and a heterogeneity in the availability of resources for mental health throughout the country.
\end{abstract}

\section{АННОТАЦИЯ}

В 1978 году в Италии принятие Закона Базальи, предусматривающего реформу психиатрии, ознаменовал переход от стационарной к внебольничной системе оказания помощи в области охраны психического здоровья. Основная цель реформы состояла в том, чтобы пациенты получали лечение по месту жительства, а не в психиатрических больницах. Следуя итальянской модели, аналогичные системы оказания психиатрической помощи получили широкое распространение в мире. Внебольничная модель оказания помощи ориентирована на содействие интеграции в общество и соблюдение прав человека в отношении лиц с психическими расстройствами, т.к. она предусматривает свободу выбора пациентами вида лечения.

К 2000 году все психиатрические больницы были закрыты, а все пациенты выписаны. Психиатрическая помощь осуществляется через Департамент психического здоровья, который является головной организацией, отвечающей за соответствующую специализированную помощь по территориальному 
принципу; сюда входят психиатрические отделения, открытые в больницах общего профиля, учреждения интернатного типа, центры психического здоровья, дневные стационары и отделения дневного пребывания.

Принятие Закона 180 привело к практическому и идеологическому сдвигу в том, что касается оказания помощи пациентам с психическими расстройствами. В частности, реформа подчеркнула необходимость лечить такого рода пациентов так же, как и любого другого пациента, а психиатрическая служба перешла от модели, предусматривающей оказание помощи в закрытом учреждении (недобровольная госпитализация), к модели терапевтической.

В Италии на протяжении последних 40 лет наблюдается последовательное совершенствование внебольничной психиатрической помощи. Однако некоторые причины для беспокойства все еще существуют, в том числе недостаточная укомплектованность персоналом, потенциальное использование общественных жилых объектов для долговременного проживания, а также неравномерность доступности ресурсов, обеспечивающих психическое здоровье, применительно ко всей стране.

Key words: mental health care; community mental health system; mental health centres Ключевые слова: психиатрическая помощь, система внебольничной психиатрической помощи; чентры психического здоровья

\section{BACKGROUND}

In Italy, the shift from asylum-based to community-based mental health services was marked by approval of Law 180 (also known as the "Basaglia law") in 1978. The approval of this reform law led to the development of community mental health services, with the aim of treating patients in the community and no longer in hospitals. Following the Italian model of mental health care, similar initiatives have been carried out in other countries worldwide. ${ }^{1}$

Law 180 started the dismantling of psychiatric asylums and development of community-based mental health centres, with a focus on people with severe mental disorders being treated in the community. ${ }^{2}$ Mental health services were established in order to cover a given geographic area and with an emphasis on possible reduction of rates of inpatient care. The communitybased model aims to promote integration and human rights for people with mental disorders on the basis of their freedom to choose treatment options. ${ }^{3}$

In Italy, the National Health System (NHS) was established on December 23, 1978, and a comprehensive public health policy was adopted. The NHS is tax-funded, covers all citizens, and absorbs approximately $7 \%$ of the whole gross domestic product. A further $2 \%$ of the gross domestic product is spent on private health services by individual citizens on a voluntary, additional basis. Approximately $5 \%$ of $\mathrm{NHS}$ resources are allocated to child and adult psychiatry, excluding services for drug abuse and learning disabilities. The National Health System consists of 206 local health trusts, each caring for a geographically defined population of 200 to 800,000 inhabitants.

Italy is characterized by several regional differences in terms of income, economic activity, distribution of wealth, rates of unemployment, development of welfare services, and other social determinants of mental health; these disparities are also reflected in the services offered by the NHS.

It took nearly 20 years to complete the deinstitutionalization process, which started in 1978 and terminated in 2000. Learning from our experience of the historical and decisive anti-institutional movement in this country is fundamental, especially if we are to understand the extent to which it is possible to change the nature of psychiatry and promote more respectful care. ${ }^{4}$

Law 180/1978 was absorbed in the general 833/78 law, through which the organization of a new National Health System was established. The structural organization of mental health departments, with a specific focus on prevention, treatment and rehabilitation of people with mental health problems, was defined by two "Progetti Obiettivo", one in 1994 and one in 1998. The second "Progetto Obiettivo" also highlighted the importance of coordination among various mental health professionals. 
In Italy, the transition from a hospital-based system of care to a community-based mental health care system started with the gradual closing down of psychiatric hospitals. In 1978, 78,538 individuals were living in psychiatric hospitals; there were 7,704 in 1998. By 2000, all psychiatric hospitals had been closed and all patients discharged. There are currently 10 beds in psychiatric wards located in general hospitals per 100,000 population and 46 beds in community residential facilities per 100,000 population, although several differences exist according to different geographic areas (Table 1).

\section{THE ORGANIZATION OF MENTAL HEALTH CARE}

\section{Department of Mental Health}

The Department of Mental Health (DMH) is the health organization responsible for specialist mental health care in the community, as defined by the Progetto Obiettivo "Tutela Salute Mentale 1998-2000". The $\mathrm{DMH}$ includes the following facilities: community mental health centres (CMHCs), day care facilities (DCF), general hospital psychiatric units (GHPUs) and residential facilities (RFs).

The DMH plays a central role in planning, organization and management of all medical and social resources related to prevention, treatment and rehabilitative interventions supporting mental health in a defined catchment area (Figure 1). Moreover, the DMH promotes informative and educational interventions for the general population in relation to mental health, in order to challenge stigmatization and discrimination against people with severe mental disorders. In particular, the $\mathrm{DMH}$ can lead research projects on the quality and efficacy of pharmacological and non-pharmacological interventions and promote training courses for mental health professionals.

\section{Community mental health centres (CMHCs)}

Community mental health centres (CMHCs) are the core of the community-based system. They cover all activities pertaining to adult psychiatry in outpatient settings, and they manage therapeutic and rehabilitation activities delivered by daily-care and residential facilities. Community mental health centres are active every day for 24 or 12 hours, depending on the regional organization. They include a multidisciplinary staff comprising psychiatrists, psychologists, social workers, rehabilitation therapists and nurses, who collaborate in order to provide integrated and personalized interventions for patients with severe mental disorders.

According to the PROG-CSM survey, ${ }^{5}$ at the national level, the $\mathrm{CMHC} /$ resident ratio is about $1 \mathrm{CMHC}$ per 80,460 inhabitants. In terms of staff working in each CMHC, the team usually includes four psychiatrists, two psychologists, two social workers or rehabilitation therapists and eight nurses. The mean is about 24.8 full-time professionals per 100,000 residents. Some differences exist at the national level: the average is 25.9 professionals per 100,000 residents $( \pm 11.5)$ in northern Italy, $28.3( \pm 7.4)$ in central Italy, and $23.7( \pm 6.9)$ residents in southern Italy.

\section{Acute inpatient units}

Within the DMH system, acute inpatient care is delivered in general hospital psychiatric units (GHPUs). These are

Table 1. Staff and resources for mental health care in Italy ${ }^{10}$

\begin{tabular}{|l|l|}
\hline Staff in mental health sector per $\mathbf{1 0 0 , 0 0 0}$ & 7.83 \\
\hline Psychiatrists & 19.28 \\
\hline Nurses & 1.93 \\
\hline Social workers & 2.58 \\
\hline Psychologists & 10.95 \\
\hline Inpatient facilities & 46.41 \\
\hline Beds for mental health in general hospitals & \\
\hline Beds in community residential facilities & 1.43 \\
\hline Outpatient facilities & 1.34 \\
\hline Outpatient mental health facilities & \\
\hline Day treatment facilities & \\
\hline
\end{tabular}




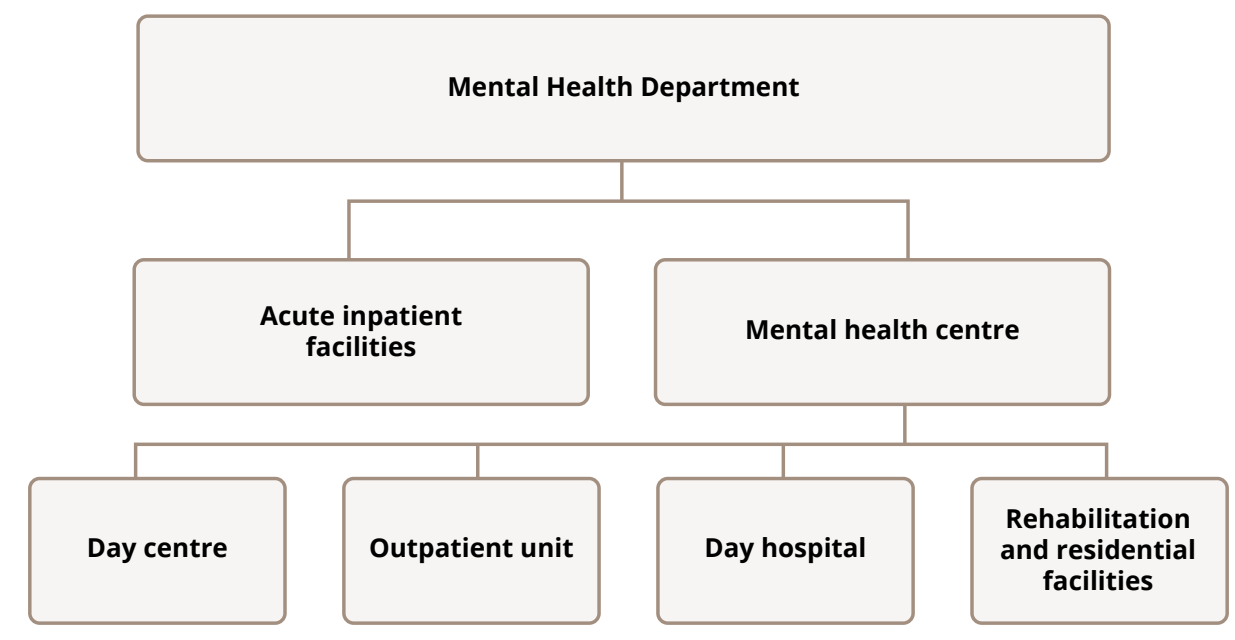

Figure 1. Organization of mental health care in Italy

inpatient facilities with a maximum of 15 beds and are closely linked with the CMHCs in order to ensure continuity of care. Admissions to a GHPU can be on a voluntary or a compulsory basis. For compulsory admissions, it is necessary for three criteria to be met, as follows: the patient has a severe mental disorder; he/she does not accept proposed treatments; the proposed treatments cannot be provided elsewhere.

\section{Day centres}

Short- and medium-term rehabilitation programmes are usually implemented in day centres.

These are generally open 8 hours per day from Monday to Saturday and can accommodate 20 patients per day. In particular, mental health professionals working in day centres promote expressive activities and conduct training and empowerment workshops through small group activities in order to improve individuals' relational abilities. Day centres are usually accessed by sub-acute patients.

\section{Community residential facilities}

Community residential facilities are non-hospital, community-based facilities that provide overnight care for patients with severe mental disorders. People living in these residential facilities have relatively stable mental health conditions and require rehabilitation interventions. These residential facilities are classified as high-, medium- or low-intensity of care reflecting the level of patient autonomy. The main difference is the number of beds: high-intensity facilities include up to 14 beds; medium-intensity facilities include up to eight beds; and low-intensity facilities have three beds. Moreover, according to the intensity of the rehabilitation interventions provided to patients, residential facilities can be classified in terms of high-, medium- or lowintensity of therapeutic interventions.

In Italy, both public and private non-profit and for-profit facilities are available. The main focus of these facilities is rehabilitation, with the development of personalized intervention plans for each patient. However, it has been found that the length of stay in such residential facilities often exceeds two years. Available data may suggest that these facilities, rather than focusing on rehabilitation, provide inpatient care and long-stay residential services. ${ }^{6}$

Service use data relating to mental health care in Italian regions

In Italy, there remains extreme variability in the provision of mental health care in different regions. In particular, the prevalence of treated mental disorders, which can be considered as a proxy indicator of the coverage capacity of community psychiatric services, ranges from 205 individuals per 10,000 population in Emilia 
Romagna (northern Italy) to 108 in Basilicata (southern Italy). ${ }^{7}$ Similar differences can be found for the incidence of treated mental disorders, although a north to south gradient has not been found; in fact, the incidence of mental disorders is higher in Liguria and Friuli (both regions of northern Italy) and lower in Lombardy (northern Italy), Tuscany, Umbria and Marche (all from central Italy) and Basilicata (southern Italy). The rate of compulsory admissions is $1.73 / 10,000$ population, ranging from 5.68 in Marche (central Italy) to 0.43 in Friuli and 0.22 in Bolzano (northern Italy).

After implementation of Law 180, the absolute number of compulsory admissions progressively declined, from more than 20,000 in 1978 to less than 9,000 in 2015. Similarly, the proportion of compulsory psychiatric admissions progressively declined from 1978 to 2005, and remained stable thereafter, accounting for less than $5 \%$ of all psychiatric admissions.

\section{DISCUSSION}

Approval of Law 180 led to a shift in the provision of care to patients with mental disorders. In particular, this law highlighted the need to treat patients with severe mental disorders the same way as all other patients. Therefore, mental health care moved from a custodialistic to a therapeutic model. In order to accommodate this clinical, ethical, social and ideological change, all asylums were closed. ${ }^{8}$ Psychiatric wards were opened within general hospitals, and a community-based model of care was implemented. ${ }^{6}$ The need for multidisciplinary èquipes to care for patients with severe mental disorders became immediately clear; the care of patients with severe mental disorders is now provided not only by psychiatrists but also by psychologists, psychiatric nurses, social workers, rehabilitation technicians and other mental health professionals working in multidisciplinary teams in order to provide personalized and integrated treatments for each patient. ${ }^{9}$

Nevertheless, according to the WHO ATLAS, the ratio of mental health professionals to the population in Italy is below the optimal standard. ${ }^{10}$ In particular, there are 33 workers per 100,000 people, which is below the median of 43.5/100,000 population in Europe and below the median of 52.3/100,000 population in high-income countries. The global median is $9 / 100,000$ population, or less than one mental health worker for 10,000 people. In terms of regional differences, a marked variation in service provision exists for different areas of the country, especially between northern vs. central and southern Italy. During the last 40 years, progressive consolidation of the community-based mental health care system has been observed. In particular, the Italian experience suggests that the number of psychiatric beds does not represent a key factor in terms of public health indicators such as suicide rates, involuntary admissions and the number of people placed in forensic facilities. ${ }^{4}$

However, some reasons for concern still exist, including low staffing levels, potential use of community residential facilities as long-stay residential services, and lack of community alternatives to acute inpatient admissions.11,12 Moreover, many authors have highlighted the high heterogeneity in available resources for mental health care in different Italian regions. In fact, in some regions - with low levels of mental health resources - the burden of mental disorders is mainly carried out by patients' families. ${ }^{13,14}$ Indeed, the high levels of family burden represent a detrimental consequence of mental disorders and have a significant impact on society at large. In order to reduce the burden reported by family members and by their ill relatives, the need to provide psychoeducational family interventions to patients and their relatives has been repeatedly stated. ${ }^{15-20}$ Unfortunately, only $8 \%$ of family members report receiving such interventions, although most of them are in close contact with mental health professionals. Obstacles faced during implementation of these interventions in routine care include excessive workload for mental health professionals, the difficulties of including these interventions in routine work, and the need to conduct such interventions outside working hours. ${ }^{21}$

After implementation of the Italian reform, the absolute number of involuntary admissions progressively declined, from more than 20,000 in 1978 to less than 9,000 in 2015. With approval of the reform, criteria for involuntary hospitalizations were made clear, but the use of involuntary admissions still remains one of the most controversial issues in mental health practice in Italy. ${ }^{22,23}$

Another element of concern is represented by the length of stay in community residential facilities. Available data show that patients stay in these facilities for up 
to two years, although there are some regional variations.

Finally, one of the most relevant aspects of the Italian law is the focus on the person suffering from mental disorders and the importance of dignifying individuals with treatment in adequate care settings.

\section{CONCLUSIONS}

In conclusion, we believe that the organization of Italian mental health care - albeit one of the oldest models in the whole of Europe - is still modern and up to date. However, the new mission of psychiatry includes prevention and treatment of new forms of mental health problems, as well as management of special patient populations, such as migrants, ${ }^{24,25}$ adolescents ${ }^{26,27}$ and elderly people. It is time for a rethink of the structure of mental health departments in order to accommodate the needs of these patients. ${ }^{28-30}$

Funding: The research was carried out without additional funding.

Conflict of Interest: The authors report no conflicts of interest.

\section{Correspondence to:}

Prof. Andrea Fiorillo, MD, PhD

andrea.fiorillo@unicampania.it

\section{For citation:}

Sampogna G, del Vecchio V, de Rosa C, et.al. Community mental health services in Italy. Consortium Psychiatricum. 2021;2(2):86-92. doi:10.17816/CP76

\section{References}

1. Catanesi R, Manna A, Ventriglio A. Community mental health services and responsibility of psychiatrists in Italy: Lessons for the globe. Int J Soc Psychiatry. 2016;62(6):501-4.

2. Ferrannini $L$, Ghio $L$, Gibertoni $D$, et al. Thirty-five years of community psychiatry in Italy. J Nerv Ment Dis. 2014;202:432-9.

3. Castaldelli-Maia JM, Ventriglio A. The impact of Basaglia on Brazilian psychiatry. Int J Soc Psychiatry. 2016;62(5):411-4.

4. Mezzina C. Forty years of the Law 180: the aspirations of a great reform, its successes and continuing need. Epidemiol Psychiatr Sci. 2018;27(4):336-345.

5. Munizza C, Gonella R, Pinciaroli L, Rucci P, Picci RL, Tibaldi G. CMHC adherence to National Mental Health Plan standards in Italy: a survey 30 years after national reform law. Psychiatr Serv.. 2011;62(9):1090-3.

6. Barbui C, Papola D, Saraceno B. Forty years without mental hospitals in Italy. Int J Ment Health Syst. 2018;(1):12:43.

7. Ministero della Salute. Rapporto sulla Salute mentale anno 2015. http://www.salut e.gov.it/porta le/news/p3_2_1_1_1.jsp?lingu a=itali

8. Fiorillo A, Ventriglio A. The legacy of Italian psychiatry. Int Rev Psychiatry. 2018;30(2):118-119.

9. Pingani L, Fiorillo A, Luciano M, Catellani S, Vinci V, Ferrari S, Rigatelli M. Who cares for it? How to provide psychosocial interventions in the community. Int J Soc Psychiatry. 2013;59(7):701-5.

10. World Health Organization. Mental health atlas 2017. Geneva: World Health Organization; 2018.

11. de Girolamo G, Bassi M, Neri G, Ruggeri M, Santone G, Picardi A. The current state of mental health care in Italy: problems, perspectives, and lessons to learn. Eur Arch Psychiatry Clin Neurosci. 2007;257(1):83-91.

12. de Girolamo G, Picardi A, Santone G, et al. The severely mentally ill in residential facilities: a national survey in Italy. Psychol Med. 2005;35(1):421-431.

13. Del Vecchio V, Luciano M, Sampogna G, De Rosa C, Giacco D, Tarricone I, Catapano F, Fiorillo A. The role of relatives in pathways to care of patients with a first episode of psychosis. Int J Soc Psychiatry. 2015; 61(7):631-637.

14. Volpe U, Fiorillo A, Luciano $M$, Del Vecchio V, Palumbo C, Calò S, Piras S, Signorelli M, Filippo D, Piselli M, De Fazio P, Gotelli S, Bardicchia F, Cerveri G, Ferrari S, Mulè A, Ribolsi M, Sampogna G, De Rosa C, Sartorius N. Pathways to mental health care in Italy: results from a multicenter study. Int J Soc Psychiatry. 2014;60(5):508-513.

15. Fiorillo A, Del Vecchio V, Luciano M, Sampogna G, De Rosa C, Malangone C, Volpe U, Bardicchia F, Ciampini G, Crocamo C, Iapichino S, Lampis D, Moroni A, Orlandi E, Piselli M, Pompili E, Veltro F, Carrà G, Maj M. Efficacy of psychoeducational family intervention for bipolar I disorder: A controlled, multicentric, realworld study. J Affect Disord. 2015;172(1):291-299.

16. Luciano M, Del Vecchio V, Sampogna G, De Rosa C, Fiorillo A. Including family members in psychoeducation for bipolar disorder: is it worth it? Bipolar Disord.. 2015;17(4):458-9.

17. Luciano M, Del Vecchio V, Giacco D, De Rosa C, Malangone C, Fiorillo A. A 'family affair'? The impact of family psychoeducational interventions on depression. Expert Rev Neurother. 2012;12(1):83-91.

18. Luciano M, Sampogna $G$, del Vecchio V, Giacco D, Mulè A, de Rosa C, Fiorillo A, Maj M. The family in Italy: cultural changes and implications for treatment. Int Rev Psychiatry.. 2012;24(2):149-156.

19. Sampogna G, Luciano M, Del Vecchio V, Malangone C, De Rosa C, Giallonardo V, Borriello G, Pocai B, Savorani M, Steardo L Jr, Lampis D, Veltro F, Bartoli F, Bardicchia F, Moroni AM, Ciampini G, Orlandi E, Ferrari S, Biondi S, Iapichino S, Pompili E, Piselli M, Tortorella A, Carrà G, Fiorillo A. The effects of psychoeducational family intervention on coping strategies of relatives of patients with bipolar I disorder: results from a controlled, real-world, multicentric study. Neuropsychiatr Dis Treat. 2018;14:977-989.

20. Steardo L Jr, Caivano V, Sampogna G, Di Cerbo A, Fico G, Zinno F, Del Vecchio V, Giallonardo V, Torella M, Luciano M, Fiorillo A. Psychoeducational Intervention for Perinatal Depression: Study Protocol of a Randomized Controlled Trial. Front Psychiatry. 2019;10:55.

21. Fiorillo A, Del Vecchio V, Luciano M, Sampogna G, Sbordone D, Catapano F, De Rosa C, Malangone C, Tortorella A, Veltro F, Nicolò G, Piselli M, Bardicchia F, Ciampini G, Lampis D, Moroni A, Bassi M, lapichino S, Biondi S, Graziani A, Orlandi E, Starace F, Baronessa C, Carrà G, Maj M. Feasibility of a psychoeducational family 
intervention for people with bipolar I disorder and their relatives: Results from an Italian real-world multicentre study. J Affect Disord.. 2016; 190(1):657-662.

22. Fiorillo A, De Rosa C, Del Vecchio V, Jurjanz L, Schnall K, Onchev G, Alexiev S, Raboch J, Kalisova L, Mastrogianni A, Georgiadou E, Solomon Z, Dembinskas A, Raskauskas V, Nawka P, Nawka A, Kiejna A, Hadrys T, Torres-Gonzales F, Mayoral F, Björkdahl A, Kjellin L, Priebe S, Maj M, Kallert T. How to improve clinical practice on involuntary hospital admissions of psychiatric patients: suggestions from the EUNOMIA study. Eur Psychiatry. 2011;26(4):201-7.

23. Luciano M, De Rosa C, Sampogna G, Del Vecchio V, Giallonardo V, Fabrazzo M, Catapano F, Onchev G, Raboch J, Mastrogianni A Solomon Z, Dembinskas A, Nawka P, Kiejna A, Torres-Gonzales F, Kjellin L, Kallert T, Fiorillo A. How to improve clinical practice on forced medication in psychiatric practice: Suggestions from the EUNOMIA European multicentre study. Eur Psychiatry. 2018;54(1):35-40.

24. Morgan C, Knowles G, Hutchinson G. Migration, ethnicity and psychoses: evidence, models and future directions. World Psychiatry. 2019;18(3):247-258.

25. Forte A, Trobia F, Gualtieri F, Lamis DA, Cardamone G, Giallonardo V, Fiorillo A, Girardi P, Pompili M. Suicide Risk among Immigrants and Ethnic Minorities: A Literature Overview. Int J Environ Res Public Health. 2018;15(7):1438.
26. Guloksuz S, Pries LK, Ten Have M, de Graaf R, van Dorsselaer S, Klingenberg B, Bak M, Lin BD, van Eijk KR, Delespaul P, van Amelsvoort T, Luykx J, Rutten BPF, van Os J. Association of preceding psychosis risk states and non-psychotic mental disorders with incidence of clinical psychosis in the general population: a prospective study in the NEMESIS-2 cohort. World Psychiatry 2020;19(1):199-205.

27. Bloomfield MAP, Chang T, Woodl MJ, Lyons LM, Cheng Z, BauerStaeb C, Hobbs C, Bracke S, Kennerley H, Isham L, Brewin C, Billings J, Greene T, Lewis G. Psychological processes mediating the association between developmental trauma and specific psychotic symptoms in adults: a systematic review and metaanalysis. World Psychiatry. 2021;20(1):107-123.

28. Fiorillo A, Maj M. The role of psychiatry in modern medicine. Int Rev Psychiatry. 2018;30(2):169-175.

29. Fiorillo A, Malik A, Luciano M, Del Vecchio V, Sampogna G, Del Gaudio L, Rojnic Kuzman M, Jovanovic N, Nawka A, Volpe $U$. Challenges for trainees in psychiatry and early career psychiatrists. Int Rev Psychiatry.. 2013;25(4):431-437.

30. Amaddeo F, Barbui C, Tansella M. State of psychiatry in Italy 35 years after psychiatric reform. A critical appraisal of national and local data. Int Rev Psychiatry. 2012;24(1):314-20. 